\title{
Methodology of Islamic Studies in The East and in The West: A Comparative Review on The Study of Hadith
}

\author{
Nabila El Chirri \\ Ushuluddin Faculty of UIN Riau, Indonesia \\ E-mail: nabilaelchirri17@gmail.com
}

\begin{abstract}
Methodology of Islamic Studies in the East and in The West: A Comparative Review. Discourse on Islam and hadith seems to always attract the attention of many people, both Muslims and non-Muslims. It is proven until now, studies of hadith both concerning the criticism of its authenticity, as well as the methodology of its understanding continue to grow. The hadith of the Prophet, or often referred to the Sunnah of the Prophet, does not only attract the attention of Muslims and Muslim scientists to study and understand more about it. A number of Western scholars (non-Muslims) are also seen to have serious concerns on this issue. They are studying many of the Prophet's hadiths, especially regarding its authenticity. They have long been interested in Islamic studies, hadiths and writing texts of hadith, they focus on the main (text) of the hadith material, and the sanad (narrator of hadith), this approach they call the study of analysis of sanad (isnad-analytical study).
\end{abstract}

Keywords: methodology, Islamic studies, study of Hadits

\section{Introduction}

Hadith is not only can be understood by a textual approach, but hadith must be understood from various dimensions. Beside of that, it should be noted the situation and condition of the incident, because the Prophet SAW often issued his lectures by adapting to the circumstances that he faced in that era. He gave a contextual answer for who asked the question to him. For who asked about God's best deeds and favor, the Prophet responds according to the situation of the time and who asked the questions, so that the hadith is not only understood in the form of textual but also understood the substance of the hadith that makes us

AJIS : Academic Journal of Islamic Studies vol. 2, no. 2, 2017

Postgraduate of STAIN Curup - Bengkulu | p-ISSN 2580-3174, e-ISSN 2580-3190

Available online: http://journal.staincurup.ac.id/index.php/AJIS 
intelligent, a more sincere heart, better morals, healthier future and wiser behavior. ${ }^{1}$

According to Ibn al-Athir (544-606 AH), Prophet Muhammad SAW. is an eloquent man, easy to understand the language, soft-spoken, and clear dialect used.2 His ability to communicate in various Arabic languages accents has an impact not only on the study of the quality of the hadith, but especially on the understanding of matan (content) of hadith, ${ }^{3}$ in

1 Jawaban yang dapat direkam atas pertanyaan yang sama tersebut adalah: 1) Amal yang paling baik adalah shalat tepat pada waktunya, 2) Amal yang paling baik dan disukai Allah adalah membaca al-Qur'an sepanjang waktu, 3) Amal yang paling utama adalah iman kepada Allah dan Rasul-Nya, 4) Amal yang paling utama adalah menahan diri dari mengganggu dan menyakiti manusia, 5) Amal yang paling baik adalah memberikan makanan kepada fakir miskin dan memberikan salam kepada siapa saja.

Hadis-hadis tersebut tidak dapat hanya dipahami secara harfiah-literal-atomistis, namun dapat dipahami latar belakang sejarahnya, bagaimana dan dalam situasi apa Nabi SAW mengucapkan sabda hadis tersebut. Selain itu juga harus dipahami apakah ketentuan yang pernah disabdakan oleh Nabi tersebut berlaku umum atau merupakan ketentuan khusus dan tidak bisa dilakukan oleh orang lain dan di tempat lain. Nizar Ali, Hadis Versus Sains (Memahami Hadis-hadis Musykil) (Yogyakarta: Teras, 2008), 6.

2 Abū Alī Muhammad 'Abd al-Raḥmān ibn Abd al-Rahịm al-Mubarakfurī, Muqaddimah Tuhfat al-Ahwādhi (Beirut: Dar al-fikr, 1979), 230.

3 Pengujian redaksi (matan) hadis sebenarnya sudah dilakukan sejak awal sekali, bahkan dari kalangan sahabat sudah terlihat pengujian-pengujian yang mereka lakukan. Dari beberapa kasus yang dicermati, terlihat bahwa pengujian hadis yang dilakukan sahabat adalah dengan al-Qur'an serta hadis-hadis yang lebih kuat dan masyhur yang terkadang diperkuat dengan argumen rasional dalam bentuk analogi. Pengujian hadis dengan al-Qur'an ini, bahkan pernah dilakukan oleh Aisyah terhadap hadis yang sedang disampaikan oleh Rasulullah sendiri.

Rasulullah SAW bersabda: "Barang siapa yang dihisab pasti akan diazab". Aisyah menyela: "Bukankan Allah telah berfirman: "Mereka (orang beriman) akan dihisab dengan hisab yang sangat mudah (al-Insyiqaq: 8)." Rasul lalu bersabda kembali: "Itu hanya sepintas, tetapi orang yang dihisab secara ketat, pasti akan sengsara.

Șalahuddīn Ibn Ahmad al-Adlabi, mencatat beberapa orang sahabat yang melakukan kritik terhadap hadis yang diriwayatkan oleh sahabat lain. Mereka antara lain adalah Siti Aisyah, Umar bin Khațțab, Alī ibn Abī Țalib, Abdullāh ibn Mas'ūd, dan Abdullāh ibn 'Abbas. Tetapi, di antara sekian sahabat yang melakukan pengujian terhadap hadis ini, yang paling intens adalah Siti Aisyah. Lihat karya Muḥammad Fuād 'Abd al-Bāqī, Al-Lu'lu' wa al-Marjān (Beirut: Dār al-Fikri, t.t), 299, dan Ṣalah al-Dīn ibn Ahmad al-Aḍabi, Metodologi Kritik Matan Hadis (Jakarta: Gaya Media Pratama, 2004), 85. 
addition to providing a relatively wide opportunity for the transmission of meaning, it can also cause of lafaz gharīb in the matan of hadith. ${ }^{4}$

Among the scholars of hadith is found two tendencies of understanding of the content of hadith. Both tendencies are representations in two groups that are quite dominant among Muslims, namely the restriction of traditionalist and modernist scripturalism. ${ }^{5}$ The first group's understanding only limits itself to the traditions it derives from classical scholars without considering social reality. While the understanding of the modernist group of scripturalism does not limit the tradition but consider the social context and reality that are outside of the text. The product of the understanding of hadith produced from both groups reflects two typologies of understanding, namely textual/literal understanding, and contextual understanding. ${ }^{6}$

The theory used by the textual group is a textual-legalistic-normative theory. This theory emphasizes the grammatical aspects of language. The basic argument refers to the structure of Arabic language. Since the hadith is written in Arabic, the best way to understand hadith is to refer to the structure of the Arabic language itself. The structure of the discussion at least involves two aspects, logic and grammar aspects. In the tradition of Hadith's understanding, this theory is the result of a

${ }^{4}$ Lafaz gharīb dalam hadis adalah lafaz yang terdapat pada matan hadis yang sulit dipahami. Ke-gharīb-an suatu hadis disebabkan oleh dua faktor, yakni lafaz tersebut sendiri sulit dipahami, kecuali dengan pemahaman yang mendalam atau ada petunjuk dari Nabi SAW. dan lafaz tersebut asing bagi periwayat, baik karena jarang digunakan ataupun karena perkembangan bahasa. Al-Sayyīd al-Ṣarīf 'Alī ibn Muḥammad ibn Alī alSayyīd al-Zain Abū al-Ḥasan al-Ḥusainī al-Jurjanī al-Ḥanafī, al-Ta'rīfāt (Kairo: Musțafā alBābī al-Halabī wa Șurakahu, 1938), 229.

5 Restriction of traditionalist adalah pola pemikiran keagamaan tradisional yang sempit. Pemikiran ini sangat dipengaruhi oleh tradisi ulama masa lampau, dimana hasil pemikiran ulama terdahulu dijadikan acuan dan sekaligus referensi bagi setiap persoalan kemasyarakatan yang muncul pada saat sekarang. Pola pemikiran yang demikian ini biasanya diikuti oleh komunitas masyarakat tradisional yang membanggakan tradisi, seperti kelompok pengikut pola bermazhab dalam keagamaan. Sedangkan, modernist scripturalism adalah tipe pola gerakan yang menamakan dirinya kelompok modern. Lihat Ahmad Arifin, Pergulatan Pemikiran Fiqh "Tradisi" Pola Mazhab (Jakarta: elSAQ Press, 2010), 3.

6 Syuhudi Ismail, Hadis Nabi yang Tekstual yang Kontekstual: (Telah Ma'ani al-Hadis yang Universal, Temporal, dan Lokal) (Jakarta: Bulan Bintang, 1994), 17. 
strong influence in the history of linguistic thought which gave birth to two schools of thought, they are schools of Kufa and Basrah. ${ }^{7}$

The theory of understanding of the traditions represented by the modernist group of scripturalism is historical-contextual. ${ }^{8}$ This theory attempts to understand the hadith by moving from the grammaticaltextual region to the contextual region. Mastery of grammar and style of Arabic is necessary for understanding the hadith. Without these two aspects, the understanding of the hadith cannot be done. The problem that arises later is that the hadith coming from the Prophet is in the form of a message in Arabic, but the Arabic language that has been made to a certain extent can be included in the category of culture in which it contains relative traits, and also contains an arbitrary sign system (social agreement ). Consequently, the meaning which is contained in the hadith is not all revealed and cannot be comprehensively understood by its readers, although its readers are experts in linguistics. In the hadith is easy to find words or sentences that give rise to ambiguous meaning because in terms of language is possible. This multi-meaning, the

7 Mazhab Kufah lebih menekankan pada tata bahasa Arab yang memiliki akar dan karakter yang khas sehingga kalau menemukan beberapa kata dan kalimat yang sulit dalam hadis, maka pemahamannya harus ditelurusi pada tradisi bahasa Arab klasik sebagaimana orang Arab dahulu memahaminya. Adapun mazhab Basrah yang ditekankan adalah logika universal sebagaimana yang diajarkan filsafat Yunani (Aristoteles), bukannya tata bahasa Arab yang bersifat lokal-partikular. Alasannya, hadis sebagai sumber ajaran Islam ditujukan untuk semua umat manusia tentunya memiliki logika universal yang melewati batas dan karakter lokal. Komaruddin Hidayat, Memahami Bahasa Agama: Sebuah Kajian Hermeneutik (Jakarta: Paramadina, 1996), 210.

8 Para ulama tidak puas dengan pendekatan gramatika-tekstual saja. Mereka mencoba memahami hadis dengan pendekatan historis-kontekstual, yakni untuk memahami ucapan Nabi, misalnya, hendaknya juga dipahami gaya bahasa yang digunakan, konteks sosial dan psikologis ketika Nabi Muhammad SAW bersabda serta kepada siapa ucapan itu dialamatkan. Seorang yang tidak mengetahui latar belakang sosial-budaya darimana dan dalam situasi apa sebuah hadis disabdakan, maka pesan dari sebuah hadis sulit ditangkap. Ketika hadis diterjemahkan secara literal dan dilepaskan dari konteksnya, sangat mungkin pemahaman yang muncul jauh dari yang dikehendaki oleh pembicaranya (Nabi). Pemahaman kontekstual ini lebih diperlukan lagi ketika seseorang akan menentukan sebuah formula hukum. pemahaman yang demikian ini dikenal dengan teori historis-kontekstual dalam memahami hadis. Nizar Ali, Hadis Versus Sains (Memahami Hadis-hadis Musykil) (Yogyakarta: Teras, 2008),10. 
semantical meaning is reinforced by the different levels of academic, psychological, and political interests of the search for the meaning of hadith, so that we witness the emergence of various schools of thought in Islam both in law, theology, philosophy, tasauf, and politics. The various issues disputed by the scholars cannot be solved by the uniformity of the meaning of hadith because the hadith is open to interpretation. ${ }^{9}$

\section{Islamic Studies and Study of Hadith in the Middle East.}

Referring to the books of al-Kutub al-Sittah (books of Șahị alBukhārī, al-Jāmi 'al-Șahịḥ, Sunan Abī Dāud, Sunan al-Tirmidhī, Sunan alNasā'ī, and Sunan Ibn Mājah) it can be concluded that the scholars' tendency to understand the hadith of the Prophet (s) is by using four methods:

\section{Tahlili Method (analytical method)}

Tahlilī comes from the Arabic تحليلا - يحلل - حلل which means parse. In his book History Ulum and the Quran, M. Quraish Shihab tahlilī interpret interpretation method is a method of interpretation by way of highlighting the verses of the holy quran by describing all the meaning and all the aspects contained therein in accordance with the order of reading contained in the Qur'anic Manuscripts' Uthmani. 10

As in the method tahlili (analytical) understanding the tradition is to understand the traditions of the Prophet Muhammad by describing all the aspects contained in the traditions understand and explain the meanings that are included in these traditions in accordance with the expertise and inclination lecturers. ${ }^{11}$

9 Komaruddin Hidayat, Memahami Bahasa Agama: Sebuah Kajian Hermeneutik (Jakarta: Paramadina, 1996), 165.

${ }^{10}$ Muhammad Quraish Shihab, Sejarah Ulūm dan al-Qur'an (Jakarta: Pustaka Firdaus, 1999), 172.

11 Pada dasarnya cara kerja penafsiran al-Qur'an yang menggunakan metode tahlilī juga ditemukan dalam metode tahlilī untuk memahami hadis. Langkah-langkah kerja metode ini dapat diketahui dari kitab-kitab syarah yang menggunakan metode ini di antaranya Fath al-Bārī bi Sharḥ Șạīh al-Bukhārī karangan al-Asqalānī dan kitab Irshad alSarī li Sharh Șaḥịh al-Bukhārī karangan al-Qasțalanī. dengan menganalisa kitab syarah ini secara umum, penulis mengetahui bahwa langkah yang ditempuh pengarangnya dalam memahami hadis di antaranya adalah menuliskan hadis yang akan dijelaskan; memahami 


\section{Ijmālī Method (global method)}

This method means to understand the hadith briefly, but in representation the hadith they used the literal sense of tradition with the popular language, easily understandable and readable with a literary systematic arrangement according to the hadith arrangement in the books of Hadits. ${ }^{12}$ Application of this method which can be found in the book of Sunan al-Nasa'i bi Sharh al-Suyuti Hasiyat al-Sindi.

This method has the characteristic that directly explain the hadith from beginning to the end without comparison and title determination. The hadith is explained in a short, compact and succinct language, so reading the syarah with this method is as if reading the hadith text because the ijmaliy method does not provide enough space for those who enjoin the hadith to include its interpretation further and deeper.

\section{Muqaran Method (comparative method)}

Understanding the hadith by using this method means to understand the hadith by comparing it with a hadith which has the same or similar editorial in the same case and comparing various opinions of scholars in understanding the hadith. The book Șaḥịh al-Muslim bi Sharh al-Nawāwī is one of the books that use this method.13 The book Sahīh al-Muslim bi Sharh al-Nawāwì is one of the books that use this method.

hadis kata demi kata, kalimat demi kalimat, hadis demi hadis. Maksudnya adalah memahami hadis dengan mengambil makna secara mendetail, dalam arti kata seorang peneliti harus memahami maknanya satu demi satu, baik berasal dari kata, kalimat maupun beberapa hadis; menjelaskan asbāb al-wurūd (latar belakang munculnya) hadis jika ada; mengungkapkan pemahaman-pemahaman yang pernah diberikan Nabi SAW, sahabat dan ulama sesudah itu; Menjelaskan munasabah (hubungan antara satu hadis dengan hadis lainnya); Memberikan syarahan/pemahaman terhadap hadis menurut versi pensyarah. Namun, pada umumnya syarahan ini tidak berasal dari pribadi pensyarah sendiri tapi juga merujuk kepada pendapat ulama-ulama lainnya. Buchari M. Metode Pemahaman Hadis sebuah Kajian Hermeneutika (Jakarta: Nuansa Madani, 1999), 26. Dan Abd al-Hayy al-Farmawi, al-Bidayah Fī al-Tafsìr al-Mauḍu'î: Dirasah Manhajiyah Maudu'îyah (Keiro: Maktabah Jumhuriyah), 23-37.

12 Buchari M. Metode Pemahaman Hadis sebuah Kajian Hermeneutika (Jakarta: Nuansa Madani, 1999). 36-37, Dan Abd al-Hayy al-Farmawi, al-Bidayah Fī al-Tafsīr alMauḍu'î: Dirasah Manhajiyah Maudu'īyah (Keiro: Maktabah Jumhuriyah), 38.

13 Buchari M. Metode Pemahaman Hadis sebuah Kajian Hermeneutika (Jakarta: Nuansa Madani, 1999). 43, Dan Abd al-Hayy al-Farmawi, al-Bidayah Fì al-Tafsìr alMauḍu'î: Dirasah Manhajiyah Mauḍu'īyah (Keiro: Maktabah Jumhuriyah), 39. 
Understanding the hadith by using this method has a wide scope, not only comparing the hadith with others hadith but also comparing the opinions of the expert in hadith. It also has its own scope. It is related to the editorial study and its relation to the connotation of the word or sentence it contains and includes a comparison between the content of meaning of each of the comparable hadiths. In addition, there are also differences in cases discussed by comparable hadiths.

The second aspect involves the comparison of the opinion of the officials who also has a very wide scope because the description discusses various aspects, both concerning the content of the meaning of hadith and the correlation between hadith to another.

\section{Mauḍū'î Method (thematic method)}

This method basically begins with a lughawi approach in accordance with the rules of language. It means that these hadiths must be understood with their inner meaning to be more easily captured. But this understanding is often inaccurate since the conclusions drawn are likely to be different from those of hadith and are sometimes contradictory. Therefore, there is a need for a comprehensive understanding of the hadith of the Prophet (SAW), so that there is no discovery of conflicts and ambiguities of understanding. A partial, but thorough understanding by collecting traditions that speaks of a theme. This kind of understanding is known as a thematic-correlative understanding.

This thematic-correlative hadith is the equivalent of the term tafsir maudū'i in the study of tafseer. What is meant by thematic-correlative understanding is a method of understanding of the traditions of the Prophet Muhammad, in which the related traditions in a theme or concerning a particular problem is studied and understood by considering the interrelationship of meaning between one another so that it will be in the understanding comprehensive. ${ }^{14}$

This method contains various aspects associated with it such as asbāb al-wurūd, vocabulary and supporting theories. Using this thematic

14 Edi Safri, Al-Imam al-Syafi'î: Metode Penyelesaian Hadis Mukhtalif (Padang: IAIN IB Press, 1999), 111. Dan Abd al-Hayy al-Farmawi, al-Bidayah Fī al-Tafsìr al-Mauḍu'ĩ: Dirasah Manhajiyah Maudu'īyah (Keiro: Maktabah Jumhuriyah), 39. 
method of understanding the hadith and explaining it will look more detailed and thorough since the main feature of this method is to highlight the theme or the title and topic of discussion.

These four methods are basically used in understanding the hadith of the Prophet. The existing books of syarah (description) have distinctive features and characteristics that illustrate the tendencies and methods used in understanding the hadith of the Prophet.15

According to Daniel Djuned in his book The New Paradigm of Hadith Studies, he stated that Fiqh al-Hadith is a very rarely studied hadith and modern works in the field of Ulūm al-Hadīth, call it eg Ușūl al-Hadīth 'Ajjaj al-Khatib and Mabahīth fī Ulūm al-Ḥadīth Subhi al-qalih, its contents only concerning the subject of the science of sanad, while relating to the understanding is only limited to the name of the science only. The jerking towards fiqh al-hadīth comes from non-specialist ulūm al-ḥadìth characters, such as Muhammad al-Ghazalī and Yusūf al-Qaraḍawī.16

As an observer and also one of the scholars of hadith, Yusūf alQaraḍāwī also offers a way to understand the hadiths other than those described above. According to him, the ways to understand hadith well could be the following: ${ }^{17}$

1. Understanding the Sunnah with the guidance of the Quran

2. Compile the hadith in one theme

3. Trying to compromise or to mukhtalih the traditions

4. Understanding hadith with the help of its emergence and purpose (maqashid)

5. Distinguish between changing means and fixed goals

6. Distinguish reality and conotation meaning.

7. Distinguish between the real and the unseen

8. Ensuring lafaz content.

The steps in understanding the traditions applied by Yusuf alQaradiawī are also used by other scholars such as Muhammad al-Gazali

15 Rajā' Musțafa Ḥazīz, I'lām al-Muḥadithīn wa Manāhajihim fì Qurun al-Thānī wa alThālithah al-Hijrī (Keiro: t.t., t.th.), 1-25.

16 Daniel Djuned, Paradigma Baru Studi Hadis, 3.

17 Yusuf al-Qaraḍawī, Bagaimana Memahami Hadis Nabi SAW (Terj. Judul Asli: Kaifa Nata'amalu ma'a al-Sunnah al-Nabawiyah, Penterjemah: Muhammad al-Baqir) (Bandung: Karisma, 1994), Cet. Ke-3. 92-195 
which he poured in his book as-Sunnah al-Nabāwiyah Abinan Ahl al-Fiqh was Ahl al-Hadīth.

There is also another approach that is not less important in understanding the hadith, especially the traditions of ahkam (hadiths related to shari'a law) is the approach of the rule of usul, which is to understand the traditions of the Prophet Muhammad by paying attention and guiding the rules of usul related to what has been formulated by the scholars. This needs attention because, in order to understand the purpose of a hadith or to be able to manifest the laws it contains well, it is closely related to the study of the science of ușul.18 Approach with regard to this rule of ușul has been practiced by Imam al-Shafi'i in solving the problem of understanding of mukhtalif (contradictive) Hadith.

The efforts to understand the hadith of the Prophet SAW turned because they are like getting inspiration and at the same time has opened the discourse of thought for Muslim intellectuals until this century. Various efforts and ijtihad are done to understand the hadith well and produce a correct understanding. All these efforts are conducted with the aim to maintain the originality of hadith as one of the sources of Islamic teachings and guidance in life.

The theory used by textual groups in the Middle East is the textuallegalistic-normative theory. This theory emphasizes the grammatical aspects of language. The basic argument is that although the hadith is believed to be the word of the Prophet (s), as it is written in Arabic, the best way to understand the hadith is to refer to the structure of the Arabic language itself. The structure of the discussion at least involves two aspects, language logic, and grammar aspects. In the tradition of Hadith's understanding, this theory is the result of a strong influence in the history of linguistic thought which gave birth to two schools of thought, namely the schools of Kufa and Basrah. ${ }^{19}$

\footnotetext{
18 Edi Safri, Al-Imam al-Syafi'î: Metode Penyelesaian Hadis Mukhtalif (Padang: IAIN IB Press, 1999), 98

19 Mazhab Kufah lebih menekankan pada tata bahasa Arab yang memiliki akar dan karakter yang khas sehingga kalau menemukan beberapa kata dan kalimat yang sulit dalam hadis, maka pemahamannya harus ditelurusi pada tradisi bahasa Arab klasik sebagaimana orang Arab dahulu memahaminya. Adapun mazhab Basrah yang ditekankan adalah logika universal sebagaimana yang diajarkan filsafat Yunani (Aristoteles), bukannya tata bahasa Arab yang bersifat lokal-partikular. Alasannya, hadis sebagai
} 
At the beginning of the twelfth century, scholars of hadith began to rise up on the sciences of hadith and link it with the development of modern knowledge as a result of the contact between the Islamic world and the Western world. The need for a review of the hadith study process, without the need to eliminate the autonomy of spirituality by the changing lives of modern society in the era of technology and information so widely. the Scholars who are pertinent to this problem include alQasimī, Maḥmūd al-Ṭahhān, Abū Shuhbah, Subḥi al-Ṣalīh, Muḥammad 'Ajjaj al-Khatīb, M.M. Azamī, Musțafá al-Ṣibā'ī, Nūr al-Dīn 'Itr, and Nașiruddīn al-Albanī.

Renewal in Islam or modern Islamic movement is the answer addressed to the crisis facing by Muslims of its time. ${ }^{20}$ The progressive decadence of the Ottoman empire that was a stakeholder of the Islamic caliphate, after the seventeenth century, has spawned a revival of Islam among Arabs on the edge of the Empire, most notably among them the Wahhabi movement, a puritanical reformist movement. This movement is a means that prepares a bridge to the more intellectual reform of Islam of the 20th century. ${ }^{21}$ In the understanding of the hadith of the Prophet, the philosophical or maslahah approach has been widely pursued by contemporary scholars, such as Yusūf Qaraḍawī, Muhammad al-Ghazalī, and others. ${ }^{22}$

sumber ajaran Islam ditujukan untuk semua umat manusia tentunya memiliki logika universal yang melewati batas dan karakter lokal. Komaruddin Hidayat, Memahami Bahasa Agama: Sebuah Kajian Hermeneutik (Jakarta: Paramadina, 1996), 210.

20 Dalam sejarah Islam, periode modern dimulai sejak pembukaan abad ke-19, yang ditandai dengan mulai masuknya kemajuan ilmu pengetahuan dan teknologi modern ke dunia Islam. Kontak dengan dunia Barat pun selanjutnya membawa ide-ide baru ke dunia Islam seperti rasionalisme, nasionalisme, demokrasi, dan sebagainya. Semua ini menimbulkan persoalan-persoalan baru, dan pemimpin-pemimpin Islam pun mulai memikirkan cara mengatasi persoalan-persoalan baru itu. Harun Nasution, Pembaruan dalam Islam (Jakarta: Bulan Bintang, 1975), 2.

${ }^{21}$ Harun Nasution, Pembaruan dalam Islam (Jakarta: Bulan Bintang, 1975), 25.

22 Pendekatan filosofis ini, bukanlah hal baru dalam wacana Islam. Ușul al-Fiqh sebagai metode memahami kitab suci dan khazanah Islam yang ditulis dalam bahasa Arab, bisa disebut sebagai kajian filosofis. Sebab di dalam Ușul al-Fiqh terdapat pembahasan Qiyas (analogi) yang cara kerjanya lebih luas dan sistematik dari metode logika yang ditawarkan Aristoteles, misalnya. Di samping itu, terdapat pula kaidah-kaidah syari'ah yang mencoba menyingkap tujuan dan hikmah di balik segenap aturan formal. Kaidahkaidah yang menyingkap tujuan dan hikmah syari'ah ini disebut dengan prinsip mașlaḥah. 
The philosophical approach can provide a new perspective on the spirit of the text as a whole which will, in turn, provide an understanding of the intent or purpose (madlul / hadaf) contained in a hadith. That there mentioned media (wasilah) as a container for the realization of goals is a natural thing. Understanding of hadith with a philosophical approach is done by attracting the purpose or purpose of an Apostle's utterance.

\section{Islamic Studies and Study of Hadiht in the West}

The hadith of the Prophet, or often referred to as the Sunnah of the Prophet, does not only attract the attention of Muslims and Muslim scholars to understand and study it. A number of Western scholars (nonMuslims) are also seen to have serious concerns on this issue. They are studying many of the Prophet's hadiths, especially regarding his authenticity. ${ }^{23}$

There are three civilizations that have an important role in the formation of Western scholarship and political thought: Greco-Roman, Judeo-Christian, and Islam. Each of these civilizations makes a distinctive contribution.

Arnold Toynbee argued that today's Western civilization was born

Dalam kajian Ușūl al-Fiqh, kajian tentang pendekatan filosofis telah banyak ditempuh oleh ulama, antara lain Imam al-Shāțibì melalui karyanya "al-Muwāfaqāt fí Ușūl alSharī'ah" atau yang dilakukan oleh Syekh 'Alī Aḥmad al-Jurjawī melalui karyanya "Hikmah Al-Tashrī' wa Falsafatuhu". Di dalam buku-buku tersebut, pengarangnya berusaha mengungkapkan hikmah yang terdapat di balik ajaran-ajaran agama Islam, seperti hikmah dalam perintah tentang shalat, puasa, haji, dan sebagainya. Ajaran agama dalam mengajarkan agar shalat berjamaah, tujuannya antara lain agar seseorang merasakan hikmahnya hidup secara berdampingan dengan orang lain. Dengan mengerjakan puasa misalnya, agar seseorang dapat merasakan lapar dan menimbulkan rasa iba kepada sesamanya yang hidup serba kekurangan, dan berbagai contoh lainnya. Abuddin Nata, Metodologi Studi Islam, 31.

23 Sarjana Barat sudah lama tertarik dengan kajian hadis dan penulisan teks hadis, terutama terhadap isu keontetikan dan originalitas. Pendekatan yang digunakan oleh sarjana Barat ini terhadap hadis adalah fokus terhadap matan (teks) dari materi hadis, dan juga mereka juga fokus terhadap sanad (perawi hadis), pendekatan ini mereka sebut dengan studi analisis sanad (isnad-analytical study). Lihat Halit Ozkan, The Common Link and Its Relation The Madar, Journal Islamic Law and Society, Vol.11, No.1 (2004), 42. http://www.jstor.org/stable/3399380. (Accessed: 27/01/2014). 
out of the ruins of the Greco-Roman civilization. Western civilization is a rebirth of Greco-Roman civilization With disintegration, says Toynbee, comes rebirth. The so-called Western world today is a split from the Byzantine Roman Empire split into two: Western Byzantine (Western Byzantium) and Byzantine (Eastern Byzantium), or Constantinople. ${ }^{24}$

Western scholars are indebted to the Greco-Roman civilization, as the latter two civilizations are indebted to the ancient civilizations of Mesopotamia, Egypt, India, Crete, and Persia. The West is indebted to the Greco-Romans almost in all aspects of its civilization and scientific tradition: art, science, philosophy, ethics, politics, medicine, mathematics and others. Today's western way of life, on the one hand, can be seen as a continuation of the Greek view of life; the ideals of freedom, optimism, secularism, the exaltation of the body and the mind and the cult of individualism. The current Western religious tradition also reflects transparently the ancient Greek religious traditions which view religion as entirely worldly, practical, devoted to the human interest (not God). ${ }^{25}$

If viewed historically there is no clear explanation, when and who is actually a Westerner who first studied Islam. Experts disagree, some said that it happened at the time of the war of Mutah $(8 \mathrm{H})$ then the war of Tabuk ( $9 \mathrm{H})$, where the first contact occurred between the Romans and the Muslims. While other scholars argued that it happened when the battle between the Muslims and Christians in Andalus (Spain), especially

24 Ada kekuatan sejarah yang memungkinkan terjadinya 'kelahiran kembali' sebuah peradaban, yaitu terdapatnya minoritas kreatif dalam puing-puing suatu peradaban yang mampu merespons secara positif terhadap tantangan lingkungan. Semakin canggih kemampuan minoritas kreatif itu merespons tantangan, semakin canggih pula bentuk peradaban yang dilahirkan kembali itu. Asumsi teoritis inilah yang oleh Toynbee dinamakan teori tantangan-Response (Challenge-response theory). Lihat Arnold Toynbee, Civilization on Trial (London, New York, and Toronto: Oxford University Press, 1949), 5.

25 Tradisi keilmuan Yunani-Romawi telah memberikan kepada Barat metode-metode eksperimental dan spekulatif yang peranannya sangat fundamental dalam pengembangan pengetahuan. Melalui karya-karya para sarjana dan filosof Yunani-Romawi, Barat mengenal Empirisme dan Rasionalisme. Yunani yang mengajarkan kepada Barat agar menempatkan akal di atas segalanya, akal sebagai sumber kebenaran dan lain-lain. Lihat Edward Manshal and Philiph Lee Ralph, World Civilization from Ancient to Contemporary (New York: Norton a co., 1964), 242. 
after Rasa Alphonse VI controlled Toledo in 488 H / 1085 M.26

It is worth noting, however, that the likes of Jerbert de Oraliac (9381003 AD), Adelard of Bath (1070-1135 AD), Pierre Le Venerable (10941156 AD), Gerard de Gremona (1114-1187 AD ), Leonardo Fibonacci (1170-1241 CE) and others lived in Andalus, and studied Islam in cities such as Toledo, Cordova, Sevilla, and others. Coming back from Andalus they spread their knowledge to the mainland Europe. ${ }^{27}$

The Orientalist lawsuit against hadith began in the mid-19th century, when almost all parts of the Islamic world had entered the grip of European colonialism. The question of authenticity, originality, authorship, origin, accuracy and the truth of hadith emerged, and became a central issue in Islamic studies, particularly with regard to Islamic law. This question arises from Western scholars as well as Muslim scholars. Abu Rayyah, for example, argues that the hadith of the Prophet has been corrupted or in other words the hadith of the Prophet has been lost because riwayah bi al-ma'nā (transmission of meaning, not pronunciation).28

Syamsuddin Arif explained that the person who first questioned the status of hadith in Islam was Alois Sprenger. It is based on his expression in the introduction to his book entitled Die Sunna Das Leben und die Lehre des Mohammad he has claimed that the hadith is a collection of anecdotes (fictitious but interesting stories). He also expressed his doubts about the accuracy of hadith as a source of history. His claim was also followed by his colleague one mission William Muir, orientalist from England who also reviewed the biography of Prophet Muhammad SAW and history of Islamic development. ${ }^{29}$

${ }^{26}$ Ada juga yang berpendapat bahwa hal itu terjadi ketika orang-orang Barat merasa terdesak oleh ekspansi Islam, terutama setelah jatuhnya Istanbul pada tahun $857 \mathrm{H}$ ke tangan kaum Muslimin di mana kemudian mereka masuk ke Wina. Orang-orang Barat merasa perlu untuk membendung ekspansi ini, sekaligus untuk mempertahankan eksistensi kaum Nashrani. Lihat Ali Mustafa Ya'qub, Kritik Hadis (Jakarta: Pustaka Firdaus, 2011), 7.

27 Ali Mustafa Ya'qub, Kritik Hadis (Jakarta: Pustaka Firdaus, 2011), 7.

28 Mahmud Abu Rayyah, Aḍwa 'alā As-Sunnah Al-Muhammadiyah (Kairo, t.tp., 1958), 55.

${ }^{29}$ Syamsuddin Arif, Orientalis dan Diabolisme Pemikiran (Jakarta: Gema Insani, 2008), 28. 
Islamic studies conducted by Westerners were originally aimed solely at Islamic material in general, including literature and history. It was only in recent times that they directed their study specifically to the field of Nabawi hadith.

In the nineteenth and twentieth centuries Western scholars, such as Goldziher, Schacht, and Juynboll, began to doubt the validity of the theories of criticism of hadith used by Muslim scholars and questioned the authenticity of the Prophetic traditions contained in canonical hadith books. ${ }^{30}$ As a result, they begin to formulate new theory theories that are supposed to be really able to select and separate the false traditions from the sahịh. Among them they use the common link method in the study of hadith.

The concept of common links and their methodological implications are systematically used in scholarship of Muslim hadith, it has extensively been used as a very powerful research tool in the scholarship of Western hadith, although some Western scholars have rejected it. However, common links have been interpreted differently. The difference lies not only in determining common links but also on whether common links are

\footnotetext{
30 Josep Schacht misalnya merumuskan teori common link untuk meneliti asal usul dan otentisitas hadis Nabi. Dan masa berikutnya teori ini dikembangkan oleh Juynboll, salah seorang sarjana Barat yang juga memiliki perhatian besar terhadap hadis Nabi. Tokoh ini bahkan telah lebih dari dua puluh tahun melakukan penelitian atas berbagai hadis Nabi dengan menggunakan teori common link, Juynboll sampai pada kesimpulan bahwa sejumlah hadis Nabi yang terdapat dalam kitab kitab kanonis tebukti tidak memiliki klaim kesejarahan. Ini berarti bahwa hadis hadis tersebut adalah palsu (tidak benar benar berasal dari Nabi).

Meskipun teori dan metode Schacht telah banyak mendapatkan kritikan dan sanggahan, namun teori tersebut tetap diadopsi dan dikembangkan oleh Gauthier Juynboll. Menurut Juynbll, hadis-hadis yang dimuat dalam kitab Șahịh al-Bukharī atau Șahịh Muslim sekalipun belum tentu berarti hadis itu otentik dan punya landasan sejarah yang pasti, karena metode kritik hadis yang digunakan sarjana Muslim memiliki banyak kelemahan dan belum mampu untuk membuktikan kemurnian dan keaslian sebuah hadis. Atas dasar itu, Juynboll menawarkan metode kritik hadis common link sebagai ganti dari metode kritik hadis para sarjana Muslim. Metode common link ternyata tidak hanya bermaksud untuk merevisi metode kritik konvensional para ahli hadis, tetapi juga menolak seluruh asumsi dasar yang menjadi pijakan bagi metode itu. Sebagaimana diketahui metode kritik hadis konvensional berpijak pada kualitas periwayat, maka metode common link tidak hanya berpijak pada kualitas periwayat namun berpijak pula pada kuantitas periwayatnya. Lihat Ali Masrur, Teori Common Link G.H.A. Juynboll (Yogyakarta: LKiS Pelangi Aksara, 2007), 2.
} 
considered as the originators (or initiators) of a particular hadith. Interestingly enough, using the common link theory, a number of Western scholars of late have succeeded in naming a number of hadiths earlier than Schacht, the champion of this concept, while other Western scholars date more recently. Meanwhile, the use of a number of Western scholars on the concept of the argumentum e silentio proved dangerous or inaccurate, especially concerning early Islamic studies. ${ }^{31}$

In the understanding of hadith, Hadith experts in the Middle East usually use a textual approach in understanding hadith, unlike the approach used by Western scholars who tend to be more contextual.

31 G.H.A. Juynboll bukanlah orang pertama yang membicarakan fenomena common link dalam periwayatan hadis. Ia mengakui dirinya sebagai pengembang dan bukan penemu dari teori tersebut. Dalam beberapa tulisannya, ia selalu merujuk kepada Schacht seraya menyetakan bahwa dialah pembuat istilah common link dan yang pertama kali memperkenalkannya dalam The Origins. Meski demikian, Schacht ternyata gagal mengamati frekuensi fenomena tersebut dan kurang memberikan perhatian dan elaborasi yang cukup memadai.

Sejak awal, fenomena common link ini sudah dikenal oleh para ahli hadis di kalangan Islam. Al-Tirmidhi dalam koleksi Hadisnya menyebut hadis-hadis, yang menunjukan adanya seorang periwayat tertentu. Si a misalnya, sebagai common link dalam isnad-nya, dengan "hadis-hadis si A". Istilah tekhnis yang dipakai al-Tirmidhi untuk menggambarkan gejala seperti itu adalah imadar (poros). Hadis-hadis itu membentuk sebagian besar hadis gharib, yaitu hadis yang diriwayatkan oleh seorang periwayat tunggal pada tabaqah (tingkatan) isnad tertentu. Akan tetapi, kelihatannya para ahli hadis dikalangan Islam tidak menyadari sepenuhnya implikasi dari gejala tersebut terhadap problem penanggalan hadis.

Schacht mengatakan bahwa teori common link dapat dipakai untuk memberikan penanggalan terhadap hadis-hadis dan doktrin-doktrin para ahli fikih. Penjelasan mengenai kepalsuan isnad bagian atas seharusnya mengubah sikap penerimaan yang tidak kritis terhadap keaslian isnad. Selain itu, ada kemungkinan bahwa nama common link hanya digunakan oleh orang lain yang tidak dikenal, dan dengan demikian kemunculannya hanya sebatas sebagai terminus a quo, khususnya pada periode tabiin. Lebih jauh mengatakan bahwa penomena semacam ini juga terjadi pada hadis-hadis yang terkait dengan sejarah.

Robson menilai teori ini sebagai sumbangan yang sangat bernilai terhadap studi perkembangan hadis karena metode itu tidak hanya memberikan penanggalan terhadap hadis yang disandarkan kepada nabi, tetapi juga menjelaskan nilai jalur isnad secara pasti bahwa bagian isnad yang timbul belakangan adalah otentik, sementara isnad bagian awal yang kembali kepada Nabi adalah palsu. Oleh karena itu, tidak mengherankan jika Juynboll ingin mengembangkan dan menerapkan teori ini dalam skala lebih luas. Lihat Kamaruddin Amin, Menguji Kembali Metode Kritik Hadis (Jakarta: Mizan Publika, 2009), 477. 
In fact, earlier Salafologists have established a methodology as an attempt to dialogue the Koran and hadith with their context. However, when brought to different contexts, the methodology is no longer able to dialogue both as needs of the new context. To keep them talking, a new methodology that can accommodate the times is needed so that both are elastic and flexible. And hermeneutics, as a study of Western-derived interpretations of texts, draws attention among Islamic thinkers to make it a study of the Qur'an and hadith. ${ }^{32}$

In all the problems of hadith, Muslim observers have been able to only enter into how to identify the șahị from the daif or asanas. Meanwhile, Western interest is to examine the hadith one by one by identifying the date of birth and death of the existing rijl al-hadith (transmittor). Thus, between the two there is indeed a difference approach is very far. However, the efforts of Western observers as Goldziher and Schacht do are valuable contributions, minimally inviting the critical and sharp sounds of what Azami says, although not a few of them merely arrive at reactive tones

The difference between the Muslim scholarly approach and the western hadith is the fundamental difference in the approach of the Islamic tradition as a whole. ${ }^{33}$

32 Dari definisi yang telah penulis kemukakan, dapatlah ditarik sebuah pengertian bahwa hermeneutik adalah suatu ilmu yang mencoba menggambarkan bagaimana sebuah kata atau suatu kejadian pada waktu dan budaya yang lalu dapat dimengerti dan menjadi bermakna secara eksistensial dalam situasi sekarang. Dengan kata lain, hermeneutik merupakan teori pengoperasian pamahaman dalam hubungannya dengan interpretasi terhadap sebuah teks. Dalam hal ini ada 3 unsur/ pilar utama hermeneutik, yaitu: (1) Penggagas, (author) komunikator atau subjek yang menyampaikan apa yang ada dalam benaknya dan hendak disampaikan kepada audiens melalui bahasa; 2) Teks (text), bahasa yang menjadi alat penyampaian, yang menjadi tanda bagi maksud ujaran tersebut; 3) Pembaca (reader), atau audiens yang menjadi sasaran pengujaran komunikator.

Namun dalam kajian hermeneutik, bukan hanya gramatika bahasa yang ditekankan, pendekatan historis, sosiologis dan antropologis juga harus dikedepankan. Dengan begitu, untuk mengetahui pesan-pesan yang ada dalam teks, harus ketahui latar belakang sosial budaya dimana dalam dalam situasi apa sebuah teks itu muncul. Lihat Yunahar Ilyas dan M. Mas'udi, Pengembangan Pemikiran Terhadap Hadis (Yogyakarta: LPPI, 1996), 3-4, dan Aksin Wijaya, Arah Baru Studi Ulum Al-Qur'an: Memburu Pesan Tuhan di Balik Fenomena Budaya (Yogyakarta: Pustaka Pelajar, 2009), 179.

33 Para sarjana Barat tidak terkesan dengan kecanggihan metode-metode untuk menentukan keaslian hadis berdasarkan sanad. Mereka cenderung menginginkan untuk 


\section{Islamic Studies and Study of Hadiht in Indonesia.}

Tracking the development of thinking in Indonesia, will not be separated from the development of relations between Muslims in the archipelago with the Islamic education center in the Middle East, especially in the seventeenth and eighteenth century is the most dynamic period in the socio-intellectual history of the Muslims. ${ }^{34}$

In the archipelago, the revitalization of the teachings of Prophet SAW contained in the hadith has been going on since the second half of the 17 th century, along with the entry of renewal ideas that emphasize the Koran and hadith as the teachings of Islam. ${ }^{35}$ The scholars examine the hadith from inspiration and insight on how to lead Muslim society towards moral social reconstruction. Nevertheless, until the early days of the twentieth century, the study of hadith in Indonesia was still less popular. ${ }^{36}$ In addition, Howard M. Federspiel also concluded the same thing, that in Indonesia the Hadith is still part of the study of Jurisprudence, not a separate study of Hadith. ${ }^{37}$

Some works on hadith in the seventeenth century up to the 18th were Bustan al-Ṣalatin, Șiratal-Mustaqīm written by Nur al-Din al-Raniri; Sharah Latīf 'alā Arbā'īn Hadīth lī Imam Al-Nawawī, and Al-Mawā'iz alBadi'ah written by Abd al-Ra'uf al-Sinkili; Sabīl al-Muhtadīn lī Tafaquh fī Amriddīn written by Sheikh Arsyad al-Banjari; Nașiḥah al-Muslīm wa Tazkirah al-Mukminīn fī Faḍa'ìl al-Jihād fī Sabīlillāh wa Karimah al-

kembali kepada matan atau muatan dari sebuah hadis. Karena mereka memiliki alasan untuk meragukan adanya hadis yang tidak berasal dari Nabi karena hadis itu membicarakan persoalan-persoalan setelah masa kewafatan Nabi. Hal ini didukung oleh fakta bahwa sebagian kaum muslim belakangan berusaha untuk menemukan dukungan bagi kelompok atau ajaran mereka dengan menyandarkan pandangan mereka kepada Muhammad.

34 Azyumardi Azra, Jaringan Ulama Timur Tengah dan Kepulauan Nusantara Abad XVII dan XVIII (Bandung: Mizan, 1994), 15.

35 Penjelasan secara mendetail pada bab selanjutnya yang menjelaskan awal perkembangan studi hadis di Indonesia. Pada bab ini penulis hanya menekankan pada penjelasan perbedaan kajian hadis di Indonesia dengan Timur Tengah dan Barat.

36 Agung Danarto, Kajian Hadis di Indonesia Tahun 1900-1945 (Telaah terhadap Pemikiran Beberapa Ulama tentang Hadis),(Yogyakarta: IAIN Sunan Kalijaga, 2000), 8. Dan Muhajirin, "Transmisi Hadis di Nusantara"(Disertasi: UIN Syarif Hidayatullah, 2009), 101.

37 Howard M. Federspiel, The Usage of Traditions of the Prophet in Contemporary Indonesia (Arizona State University, 1993), 2. 
Mujahidīn fī Sabīlillāh written by Abdul Samad al-Palimbani; Tanqih alQaul al-Ḥadīth Sharah Lubāb al-Ḥadīth, al-Dūrur al-Bahiyyaj fì Sharah alKhașāiș al-Nabawiyyah was written by Nawawi al-Bantani; Tanqi al-Qaul, Sharah Lubāb al-Ḥadīth, Nașāih al-Ibād written by Mahfudz al-Tirm; AlQawa'id al Asasiyyah li Ahl al-Sunnah wa al Jama'ah was written by Ahmad Masduki Mahfuzh; al Hadith and Aqidah Ahl al-Sunnah wal Jama'ah written by Sheikh Haji Muhammad al-Khalidi; The Ahl al-Sunnah wa al-Jama'ah fī Hadīth al Mautā wa Ashrath al-Sa'ah wa Bayan Mafhūm al-Sunnah wa al Bid'āh was written by KH. Muhammad Hashim Asy'ari; Ḥashiyah al-Nafahat 'alā Sharh al-Waraqat lil Maḥallī written by Sheikh Ahmad Khatib al-Minangkabawi.

If seen from some works of hadith in the 17th century to the 18th there are about 16 hadiths who make works about the hadith, and the work of these figures are more likely to research sanad hadith and collections of hadith only. In the seventeenth century the tendency at that time in Indonesia was the number of tarekat and tasawuf teachings so that Muslims wanted to practice the teachings of Islam by referring to the Qur'an and Sunnah, and also scholars continue to try to classify the șa had hadith with false hadith, so that many scholars of hadith made works on the hadiths and collections of hadith. ${ }^{38}$

The works of hadith in the 19th century up to the 20 of them are the Principles of Dirayah Hadith Science, Problematics of Hadith as the Basis for the Development of Islamic Law, History and Introduction to the Science of Hadith, 2002 Pearl of Hadith, Collection of Hadiths of Law written by Hasbi Ash-Shiddieqy; The Scripture of Moses was written by Mahmoud Yunus; Highlights of Mustihalah Hadith, Hadiths about Religious Courts written by Fatchurrahman; The Choice of Choice Hadis (Hadith Sahih al-Bukhari) is written by Husen Bahreisy; 123 The Hadith of Faith and Morals was written by Mustagfiri Asror; The virtue of Budi in Islam: Ihya Sunatullah wa Rasulih written by Fachruddin HS; The translation of Nail al-Authar was written by Muamal Hamidy; Tarjamah

\footnotetext{
38 Karakteristik dari karya-karya hadis di Indonesia lebih banyak bersifat pengantar dari pada pembahasan, apalagi yang bersifat analisa. Hal tersebut dapat ditunjukkan dengan sedikitnya informasi ketika menjelaskan hal-hal pokok yang berkaitan dengan hadis. Kecenderungan untuk mengkaji kajian sejarah lebih dominan daripada kajian hadis yang sesungguhnya, sehingga sekalipun masuk pada kategori karya dengan karakteristik pembahasan, kajian sejarah masih dominan daripada kajian hadis.
} 
Bulug al-Maram ibn Hajar al-Asqalani is written by A. Hassan; Hadith Arbain al-Nawawiyah written by Umar Hashim; The pearl of the Qur'an and Hadith is written by AA. Masyhuri; The translation of Sahih Muslim Hadith is written by HA Razak; The Set of 405 The Essence of Hadith (Tarjamah Jamius Shagr) was written by Mahfulli Sahli; The Grain of Education in the Hadith was written by Muhammad Talib; al-Quran and al-Hadith for Madrasah Aliyah / PGA written Muslich Marzuki; Science of Hadith is written by Debt Ranuwijaya.

In the twentieth century, Hadist works are more dominated about the science of hadith and collections of hadith, the work on the science of hadith in the twentieth century is intended to make a textbook hadith for schools and colleges. The lack of work on the science of hadith as a study at Islamic High School in Indonesia made the hadith leaders in the 20th century made works on the science of hadith and collections of hadith, so that students and students understand the science of hadith. ${ }^{39}$

The work of hadith in the 21st century is like the Critical Study of Hadith The Sosio-Historical-Contextual Approach Asbāb al-Wurud was written by Said Agil Munawwar; The study of Ma'ani al-Hadith was written by Muhammad Syuhudi Ismail; Criticism of Hadith written by Ali Mustafa Ya'qub; The reward and virtue of Hajj, the Prophet's personal: The study of the Book of Taudhih al-Dalay fi Tarjamat Hadith al-Shamail written by Lutfi Fathullah; Rethinking Hadith Critical Methods written by Kamarudin Amin; al-Sunnah fi Indonesia: Baina Ansariha wa Khusumiha written by David Rashid Sitorus; Understanding the Hadith of the Prophet: The method and approach was written by Nizar Ali; The Reconstruction of the Methodology of Understanding of Hadith, in the discourse of the study of contemporary hadith written by Suryadi; The Study of the Matan Hadith (A Methodological Offer of the Prophet's Prophets: Historical and Methodological Review) was written by Muhammad Zuhri; Keshahihan Matn al-Hadis and Methodology of Understanding of Hadith (A Hermeneutic Study) was written by Buchari

39 Pengaruh manhaj modern disebabkan adanya kesamaan dalam bentuk tujuan pembukuan, yaitu sebagai dasar acuan untuk pembelajaran materi hadis, tetapi dari segi materi berbeda. Materi dari periode modern minimal sebagai buku bersifat pembahasan, bahkan banyak yang bersifat analisis, sedangkan di Indonesia lebih dominan pengantar dan bahkan mereduksi bagian-bagian kajian hadis itu sendiri. Muhammad Dede Rodliyana, “Pergeseran Pemikiran 'Ulum Hadith”, 135. 
M; New Paradigm of Hadith Science and Reconstruction Fiqh al-Hadith written by Daniel Djuned; Modern Thought in Sunnah The Approach of the Science of Hadith is written by Abdul Majid Khon; and others.

In contrast to the present time that there is a significant development in the study of hadith. If we look at the hadith literature in Indonesia today, there are some Hadith scholars who have begun to understand the hadith with some methods and approaches such as Said Agil Munawar who understand the hadith with the socio-historical-contextual approach, and Buchari $\mathrm{M}$ understands the hadith by using the hermeneutic approach and many others have hadith scholars in Indonesia who apply some methods and approaches in understanding the hadith.

In the problem of the development of the understanding of hadith in Indonesia, Muhammad Syuhudi Ismail has also written among them Kaidah Keshahihan Sanad Hadith, Critical Review and Review with Approach of Historical Sciences, Research Methodology of Prophet Hadith, Prophetic Hadith according to his defender, denial and forgery, Summary Mushthalah Hadith, textual and contextual: the study of maani al hadis about the universal, temporal and local Islamic teachings.

M. Syuhudi Ismail is a scholar and intellectual who has considerable influence in Indonesia in the field of Hadith and Ulumul Hadith. One of his thoughts is about the method of understanding against the matan hadith in his book entitled Textual Hadiths and contextual: the study of maani al Hadith about the teachings of Islam are universal, temporal and local. According to him that there are matan hadith that must be understood in textual, contextual and some that must be understood textually and contextually as well. This shows that the content of the hadith of the Prophet is universal, temporal and local.

As exemplified by Muhammad Syuhudi Ismail in understanding the traditions that prohibit plastic surgery. The Hadith reads:

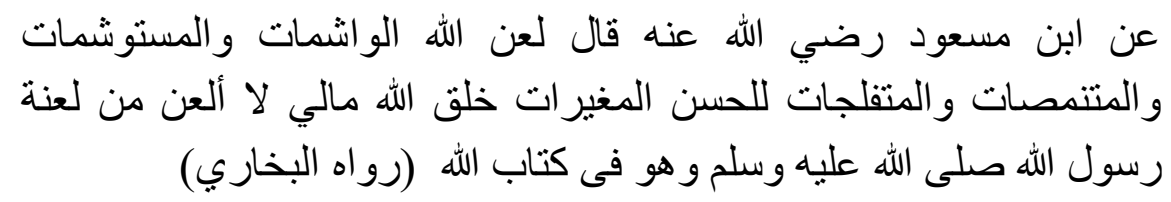

From Ibn Mas'ud r.a. he said: God has cursed those who use fake moles in the form of tattoos, people who shave his eyebrows, and flatten his 
teeth with a miser to beautify himself by changing what God has made. (Surah Ibn Masud)), I do not have (reason) not to curse the person who cursed the Messenger of Allah as set forth in the Koran (Narrated by alBukharī). 40

According to Syuhudi Ismail, plastic surgery or plastic surgery performed only for beauty purposes including acts cursed by Prophet Muhammad SAW, but if it is intended for treatment or avoid something that is harmful, then the law is allowed. In line with Syuhudi, Muhammad Yusuf al-Qaradawi allows surgery on parts of the body due to functional impairment, either due to congenital or accidental outcomes, such as cleft lip (plastic construction surgery). The plastic surgery on the part of the body that has no functional disturbance, only the shape is not perfect or want to beautified, such as nose pug nose (plastic surgery aesthetics), the legal decision of the case is haram (forbidden). ${ }^{41}$

According to Syuhudi Ismail, we must be careful in establishing the illat of a law, and to understand the above hadith, we must know well the causes of the hadith and the background of the determination of the law desired by the Prophet SAW. The illat of prohibition of making fake moles and so on for the sake of discourse is because the act has changed what has been established (made) by God. The smells, jewelry, and or hair polishes do not alter the human body at all. Therefore, it can not be analogous to plastic surgery for beauty purposes..$^{42}$

In this case, Muhammad Syuhudi Ismail tends to be textual, being very cautious, but firm in understanding the hadith about plastic surgery.

\footnotetext{
${ }^{40}$ Al-Bukharī, al-Jamī’ al-Ṣaḥīh, Juz IV, 43.

41 Muhammad Yusuf al-Qarāọawī, Halal dan Haram dalam Islam (Surabaya: Bina Ilmu, 1996), 118-119. Kata Abdul Hamid Qudah, operasi estetika mengandung faktor tidak mensyukuri nikmat Allah yang nyata-nyata berfungsi baik. Padahal, yang ditekankan di dalam Islam adalah usaha mencari sebab kesembuhan dari penyakit yang menimpa dengan cara-cara yang dibenarkan syara'. Lihat Abd al-Hamid Qudah, Abhās fi al-Adwā wa al-Tibb al-Wiqā'î (Mekah: Rabitah al-'Alam al-Islāmī, 1987), 12.

42 Syuhudi tidak mengingkari orang yang telah menjadi cantik karena operasi plastik itu makan bertambah besar rasa percaya diri dan ketenangannya. Tetapi dia mempertanyakan akibat buruk yang ditanggung oleh yang bersangkutan. Nabi SAW menegaskan bahwa pemanfaatan anggota tubuh termasuk salah satu hal yang perlu dipertanggungjawabkan di hadapan Allah kelak. Muhammad Syuhudi Ismail, "Bedah Plastik", Pedoman Rakyat, Ujungpandang, 4 Desember 1988 M.
} 
Ali Mustafa Yaqub prioritizes sanad criticism, to find out if a hadith is acceptable, and otherwise to be rejected. This is seen in the way in which to criticize a phrase, which the people say is a hadith. And it is seen from his works such as Troublemess Hadith, Imam Bukhari and Methodology Criticism in the Science of Hadith, Role of Science of Hadith in the Development of Islamic Law, Islam of Today.

As Ali Mustafa Yaqub exemplifies in the study of Hadith Who recognizes him, he recognizes his God ". According to Shaykh Muhyi alDin said that this hadith though not șahị in terms of history, but for us the hadith is sahị based on kashf method. In contrast to Ali Mustafa Ya'qub explains that it is not justified to use the kashf method to prove the authenticity of the hadith. If this kashf method is justified, then everyone can claim to have this method, and in turn false traditions may turn into a hadith șahịh. ${ }^{43}$

Buchari M, writes on the Method of Understanding of Hadith (A Hermeneutic Study), and the Mutual Keshahihan Matan Tradition. In his work Buchari $\mathrm{M}$, using the hermeneutic method of understanding a hadith, and he exemplifies some traditions that the hermeneutic method can use in understanding the hadith. ${ }^{44}$ While Daniel Djuned, writing about the New Paradigm of the Study of Hadith Science and the Reconstruction of Fiqh al-Hadith, in his work Daniel Djuned gives a solution to the understanding of the hadith, he tried to reconstruct the method of understanding the hadith so that the traditions are readily accepted by the Indonesian people in particular. ${ }^{45}$

${ }^{43}$ Ali Mustafa Ya'qub, Hadis-Hadis Bermasalah (Jakarta: Pustaka Firdaus, 2007), 79.

44 Jika kita melihat karya Buchari M ia menulis tentang perlunya metode hermeneutik dalam memahami hadis, Menurut Buchari, hermeneutik dapat digunakan dalam tatanan mafhūm al-naș (pemahaman teks), bukan dalam mengukur keontentikan naș.

45 Daniel Djuned dalam karyanya Paradigma Baru Studi Ilmu Hadis, di dalam bukunya ia menjelaskan bagaimana caranya memahami hadis yang benar. Beberapa pendekatan yang digunakan oleh Daniel Djuned dalam memahami hadis adalah dengan menggunakan pendekatan geografis, sosio-kultural, antropologis, dan sebagainya. Dalam penggunaan pendekatan geografis ia mencontohkan tentang hadis dilarangnya wanita bepergian selama tiga hari kecuali didampingi oleh mahram-nya. Ia menjelaskan bahwa berdasarkan latar belakang kondisi alam dapat dipahami bahwa larangan bepergian bagi wanita tanpa mahram di atas bersifat kondisional. Mahram menjadi persyaratan jika kondisi tidak aman. Dalam kondisi aman seperti keadaan dunia hari ini, mahram dimaksud bukan hal yang mengikat. 
According to the author's assumption, in Indonesia there is a very significant development and shift, not only in the subject of sanad science but rather on the construction, deconstruction and reconstruction of the understanding of the hadith itself.

\section{Conclusion}

The study of hadith which begins from the study of the hadith sanad, ulūm al-hadīth, to the methodology of the understanding of hadith indicates a shift in the study of hadith and the development of the understanding of hadith with scientific approach, logic-deductive, and correlation of socio-historical-psychological context in Indonesia. And the results of ijtihad of the Hadith scholars in Indonesia can not be separated from the influence of the sociocultural environment in which he lives, the political factors he supports, the reading background, the schools and the tendencies of his thinking, and the educational environment.

In terms of manhāj there has been a significant shift among the scholars of hadith. This is due to the situation and condition of the birth of thought to the existing work. The development of the preparation of works on the study of hadith has a strongly significant difference significance. That is, in each period has certain characteristics that each has a specific purpose and purpose as well.

\section{Bibliorgaphy}

Abdullah, Taufik. Metodologi Penelitian Agama: Sebuah Pengantar. Yogyakarta: Tiara Wacana, 1991.

Amin, Kamaruddin. Menguji Kembali Metode Kritik Hadis. Jakarta: Mizan Publika, 2009.

Arif, Syamsuddin. Orientalis dan Diabolisme Pemikiran. Jakarta: Gema Insani, 2008.

Ash-Shidiqie, M. Hasbi. Sejarah Ilmu Hadis. Jakarta: Bulan Bintang, 1993.

Azra, Azyumardi. Esei-Esei Intelektual Muslim dan Pendidikan Islam. Jakarta: Logos Wacana Ilmu, 1998.

Danarto, Agung. Kajian Hadis di Indonesia Tahun 1900-1945 (Telaah terhadap Pemikiran Beberapa Ulama tentang Hadis). Yogyakarta: IAIN Sunan Kalijaga, 2000. 
Al-Dimashqi, Ibnu Hamzah al-Husaini. al-Bayan wa at-Ta'rif fi Asbābī Wurudi alHadith al-sharif. Beirut: Dar al-Thaqafah al-Islamiyyah, t.th.

Al-Farmawi, Abd al-Hayy. al-Bidayah Fī al-Tafsīr al-Mauḍu'ĩ: Dirasah Manhajiyah Maudu'īyah. Keiro: Maktabah Jumhuriyah.

Fazlurrahman. Membuka Pintu Ijtihad. Bandung: Pustaka, 1995.

Federspiel, Howard M. The Usage of Traditions of the Prophet in Contemporary Indonesia. Arizona State University, 1993.

Green, Arnold W. sociology an Analysis of Life in Modern Society. New York: Toroto 1960.

Ḥazīz, Rajā' Musțafa. I'lām al-Muhadithīn wa Manāhajihim fì Qurun al-Thānī wa al-Thālithah al-Hijrī. Keiro: t.t., t.th.

Hidayat, Komaruddin. Memahami Bahasa Agama: Sebuah Kajian Hermeneutik. Jakarta: Paramadina, 1996.

Ilyas, Yunahar. Feminisme dalam Kajian Tafsir al-Qur'an Klasik dan Kontemporer. Yogyakarta: Pustaka Pelajar,1997.

Pengembangan Pemikiran Terhadap Hadis. Yogyakarta: LPPI, 1996.

Ismail, Muhammad Syuhudi. "Bedah Plastik", Pedoman Rakyat, Ujungpandang, 4 Desember 1988 M.

. Hadis Nabi yang Tekstual dan Kontekstual. Jakarta: Bulan Bintang, 1994.

Nabi Menurut Pembela Pengingkar dan Pemalsunya. Jakarta: Gema Insani Press, 1995.

M, Buchari. Metode Pemahaman Hadis sebuah Kajian Hermeneutika. Jakarta: Nuansa Madani, 1999.

Masrur, Ali. Teori Common Link G.H.A. Juynboll. Yogyakarta: LKiS Pelangi Aksara, 2007.

Manshal, Edward. World Civilization from Ancient to Contemporary. New York: Norton a co., 1964.

Menno, S. Antopologi Perkotaan. Jakarta: CV,Rajawali, 1992.

Muhajirin. "Transmisi Hadis di Nusantara”. Disertasi: UIN Syarif Hidayatullah, 2009.

Muhammad, Afif. Kritik Matan: Menuju Pendekatan Kontekstual Atas Hadis Nabi SAW, dalam Jurnal al-Hikmah, No. 5, 28. Maret-Juni 1992. 
Mujiyo. "Syarah Hadis dalam Tradisi Keilmuan Islam: Genealogi dan Metodologi". Disertasi: UIN Syarif Hidayatullah Jakarta, 2010.

Nasution, Harun. Pembaruan dalam Islam. Jakarta: Bulan Bintang, 1975.

Ozkan, Halit. The Common Link and Its Relation The Madar, Journal Islamic Law $\begin{array}{lllll}\text { and } \quad \text { Society, } & \text { Vol.11, } & \text { No.1 }\end{array}$ http://www.jstor.org/stable/3399380. (Accessed: 27/01/2014).

Palmer, Richard E. Hermeneutics. Evanton: Northwester University Press, 1969.

Polama, Margaret M. Sosiologi Kontemporer. Yogyakarta: CV Rajawali t.th.

Al-Qaraḍawī, Yusuf. Kaifa Nata'amalu ma'a al-Sunnah al-Nabawiyah. Bandung: Karisma, 1994.

Halal dan Haram dalam Islam. Surabaya: Bina Ilmu, 1996.

Qudah, Abd al-Hamid. Abhās fi al-Adwā wa al-Ṭibb al-Wiqā'î. Mekah: Rabitah al'Alam al-Islāmī, 1987.

Rayyah, Mahmud Abu. Aḍwa 'alā As-Sunnah Al-Muhammadiyah. Kairo, t.tp., 1958.

Risser, James. Hermeneutic and The Voice of The Other. State University of New York Press, 1997.

Safri, Edi. Al-Imam al-Syafi'ī: Metode Penyelesaian Hadis Mukhtalif. Padang: IAIN IB Press, 1999.

Saefuddin, Didin. Pemikiran Modern dan Postmodern Islam: Biografi Intelektual 17 Tokoh. Jakarta: Grasindo, 2003.

Al-Salafi, Muhammad Luqman. Ihtimām al-Mahaddithūn bi Naqdi al-Hadīth, Sanadan wa Matanan. Riyadh:t.t., 1987.

Al-Shaibānī, Ahmad ibn Hanbal Abū Abdillāh. Musnad Imam Ahmad ibn Hanbal. Keiro: Mu'assasah Qurtubah, tth.

Shahrur, Muhammad. al-Kitab wa al-Qur'an. Kairo: Sina, 1992.

Shihab, Muhammad Quraish. Sejarah Ulūm dan al-Qur'an. Jakarta: Pustaka Firdaus, 1999.

Al-Suyūthī, Jalal al-Din Abdurrahman ibn abi Bakar. Tadrib al-Rāwī fì Sharh Taqrib al-Nawāwī. Madinah: Maktabah Ilmiah, 1972. . Lubāb al-Nuqul dalam Hashiah Tafsir al-Jalalain. Semarang: Maktabah Usaha Keluarga,t.th.

Toynbee, Arnold. Civilization on Trial. London, New York, and Toronto: Oxford University Press, 1949. 
Wijaya, Aksin. Arah Baru Studi Ulum Al-Qur'an: Memburu Pesan Tuhan di Balik Fenomena Budaya. Yogyakarta: Pustaka Pelajar, 2009.

Woodward, Mark R. Textual Exegesis as Social Commentary: Religious, Social, and Political Meaning of Indonesian Translation of Arabic Hadith Texts, The Journal of Asian Studies, Vol. 52, No.3 (1993), 569. http://www.jstor.org/stable/2058854. (Accessed: 27/01/2014)

Ya'qub, Ali Mustafa. Hadis-Hadis Bermasalah. Jakarta: Pustaka Firdaus, 2007. Kritik Hadis. Jakarta: Pustaka Firdaus, 2011.

Zahwu, Muhammad Abū. al-Hadīth wa al-Muhaddithun. Mesir: Syirkah Misyriyyah, t.th. Zahwu, Muhammad Abū. al-Hadīth wa al-Muhaddithun. Mesir: Syirkah Misyriyyah, t.th.

Zuhaili, Wahbah. al-Qur'an al-Karim wa Bunyatuhu at-Tasyri'iyyah wa Khadhariyyah. Beirut:Dar al-Fikr, 1993. 